\title{
Üniversite Öğrencilerinin Fonksiyonel Olmayan Tutumların Genel, Kişisel ve Sosyal Uyum Düzeylerini Yordama Gücü*
}

\section{Predictive Power Of Non-Functional Attitude University Students For Their General, İndividual And Social Adjustment Levels}

\author{
Metin Çelik ${ }^{\mathrm{a}, * *}$, Yüksel Çırak ${ }^{\mathrm{b}}$ \\ ${ }^{a}$ Öğretim Görevlisi, Siirt Üniversitesi, Sosyal Bilimler MYO, Sosyal Hizmet ve Danışmanlık, 56100, Siirt/Türkiye. \\ ORCID: 0000-0001-5739-1522
}

b Dr. Öğr. Üyesi, İnönü Üniversitesi, Eğitim Fakültesi, Eğitim Bilimleri Bölümü, 44280, Malatya/Türkiye. ORCID: 0000-0001-5739-1522

\section{MAKALE BİLGİSİ}

\section{Makale Geçmişi:}

Başvuru tarihi: 01 Şubat 2019

Düzeltme tarihi: 05 Mayıs 2019

Kabul tarihi: 29 Mayıs 2019

Anahtar Kelimeler:

Uyum

Fonksiyonel Olmayan Tutumlar

Üniversite Öğrencileri

\section{A R T I C LE INFO}

\section{Article history:}

Received 01 February 2019

Received in revised form 05 May 2019

Accepted 29 May 2019

\section{Keywords:}

Adjustment

Non-Functional Attitude

University Students
ÖZ

$\mathrm{Bu}$ araștırmanın amacı üniversite öğrencilerinin fonksiyonel olmayan tutumlarının genel, kișisel ve sosyal uyum düzeylerini yordama gücünün belirlenmesidir. Araştırma modeli, ilişkisel araştırma yöntemi ile tasarlanmıştır. Araştırmanın örneklemi oran tabakalı örnekleme yöntemiyle seçilen 950 öğrenciden oluşmaktadır. Araştırmanın verileri Fonksiyonel Olmayan Tutumlar Ölçeği (FOTÖ) ve Kişisel Bilgi Formu kullanılarak toplanılmıştır. Araştırmadan elde edilen sonuçlara göre, fonksiyonel olmayan tutumlar ölçeğinin 4 alt boyutu olan mükemmeliyetçilik, onaylanma ihtiyacı, bağımsız ve değişken tutum, genel uyum düzeyindeki değişimin \%8.7'sini, kişisel uyum düzeyindeki değișimin \%6.4'nü ve sosyal uyum düzeyindeki değișimin \%9.1'ni açıklamaktadır. Standartlaştırılmış regresyon katsayılarına göre, yordayıcı değişkenlerin, genel uyum düzeyi üzerindeki göreli önem sırası, mükemmelci tutum $(\beta=-0.138)$, ve bağımsız tutum $(\beta=-0.134)$, onaylanma ihtiyacı $(\beta=-0.108)$, değişken tutumdur $(\beta=-0.047)$.

\section{A B S T R A C T}

The aim of this study is to analyze whether there is statistically significant difference between the university students' dysfunctional attitudes and their general, individual and social adjustment levels.The research model has been designed with relational research method. The sample of the research consists of 950 students selected through rate layer sampling method. The data of the research was gathered by using, Non-functional Attitude Scale and Personal Information Form. According to the results emerging from the study, perfectionism, need for approval, independent and variable attitude which are 4 sub-dimensions of non-functional attitudes scale explain $\% 8.7$ change of general adjustment level, \%6.4 change of personal adjustment level and \%9.1 change of social adjustment level. According to the normalized regression coefficient, the impact of predictor variable on general adjustment level of relativist order of importance is $(\beta=0.138)$ for perfectionist attitude, $(\beta=-0.134)$ for independent attitude, $(\beta=-0.108)$ for need for approval and $(\beta=-0.047)$ for variable attitude.

\section{Giriş}

Uyum bireyin hem bir birey olarak kendisiyle hem de etkileşim içinde olduğu toplumla sağlıklı bir ilişki içinde olması ve bu ilişsileri sürdürebilme düzeyidir. (Özgüven,
1992). Genel uyum düzeyi kişisel ve sosyal uyum olmak üzere iki kategoride ele alınmaktadır. Kişisel uyum, kişinin ruhsal yaşamının bütünüyle sağlamak istediği uyumdur. Bununla birlikte kişinin yaşamını sürdürdüğü çevrenin ilgi, arzu ve farklılaşmasına uygun tutum ve eylemlerde

\footnotetext{
* Bu çalışma birinci yazarın 2018 yılında Yüksel Çırak danışmanlığında İnönü Üniversitesi Eğitim Bilimleri Enstitüsü Rehberlik ve Psikolojik Danışmanlık Anabilim Dalı'nda yürüttüğü "Üniversite Öğrencilerinin Kişisel ve Sosyal Uyum Düzeylerinin Fonksiyonel Olmayan Tutumlar ve Çeşitli Değişkenler Açısından İncelenmesi” başlıklı yüksek lisans tezinden türetilmiştir.

** Sorumlu yazar/Corresponding author e-posta: metincelik@siirt.edu.tr
} 
bulunması kişisel uyumdan bağımsız değildir (Cüceloğlu,2015). Uyumun ikinci boyutu olan sosyal uyum ise Yavuzer (2003) göre, kişinin diğer bireylere karş1 adaptasyon içinde olabilme başarısı ve etkileşim içerisinde olduğu topluluklara karşı kendine has bir şekilde kendini gruba kabullendirebilmesidir. Uyum bireyin yaşamı boyunca karşılaşabileceği bir süreç şeklinde ele alınabilir. $\mathrm{Bu}$ süreç bazı isteklerin yerine getirilmesi şeklinde başlayıp, kişinin var olan dengelerini bozar. Yeniden dengeye geçmek için birey birtakım becerilere sahip olup, bu becerilerini geliştirebilir (Gençöz, 1998). Birey uyuma geçme sürecinde var olan dengesi bozulduğu için kaygı ve stres yaşayabilmektedir. Bireyin bu kaygı ve stres verici durumlarla baş edip yeniden uyuma geçilebilmesi için birçok etmenin belirleyici olabileceği bilinmektedir. Benight ve Bandura (2004)'ya göre, bireylerin kendilerine olan güvenleri ya da stresli bir olayın üstesinden geleceklerine dair inançları bireyin kaygı düzeyini ve o olaya verdiği tepkiyi etkilemektedir. Yine Kramer ve ark. (2014) göre, uyumlu veya uyumsuz davranışa var olan durum değil, bu durumlarla alakalı bilişsel yorumlamalar sebep olur (Kramer ve ark., 2014).

Ellis (1994) göre, inançlar bizim kendimize söylediğimiz şeylerdir veya bizim için özel bir anlamı olan imge ve sembollerdir. $\mathrm{Bu}$ inançlarımız bizim yaşam felsefemizi belirler, ondan sonrada yaşamımızın önemli bir kısmında “ 'ya ardından gidilecek ya da ortadan kaldırılacak bir şey olarak yer alır'. Akılcı Duygusal Kurama göre inançlar mantıklı ve mantıkdışı inançlar olmak üzere ikiye ayrılmaktadır. Mantıklı inançlar kişinin kendi seçimleri ve arzularıdır. Akılcı Duygusal Davranışçı Terapi (ADDT) akılcı kavramını; bireyin kendine sağlıklı bir şekilde yardım edebilmesi şeklinde tanımlar. (Murdock,2016).

Ellis (1994) göre, mantık dış1 inançlar bireyin hedeflerini gerçekleştirmesini engellerken, mantıklı inançlar bireyin hedeflerine ulaşmasında kolaylık sağlar. Akılcı Duygusal Davranışçı yaklaşım, bireyin psikolojik uyumunu bozan sebeplerinin olumsuz çevre şartlarından kaynaklanmadığını, uyumunu bozan asıl nedenin mantıkdışı davranıp kendilerini davranışsal ve duygusal olarak işlev görmeyen bir duruma getirmeleri şeklinde açıklar. Bu kurama göre kişilerdeki uyumsuzluk ve duygusal sorunların asıl sebebi akılcı olmayan inançlardır (Yurtal, 2001). Akılcı olmayan inançlardan olan mükemmeliyetçilik, bağımlı olma, onaylama ihtiyacı Jones (1969) tarafından şu şekilde açıklanmaktadır.(Akt., Yurtal-Dinç,1999).

Mükemmeliyetçilik, bireyin sorunlarının kusursuz bir çözümü olduğu ve tek bir doğru olduğu fikrine sahip olmasıdır. Bireyin karşılaştığı sorunları çözme adına olası ve pratik olanı istemesi mantıklıdır. Fakat sürekli olarak kusursuz çözüm yöntemlerini araması fonksiyonel olmayan bir tutumdur. Mükemmeliyetçi bireyler problemlerini çözüme kavuşturacak yolların bütün ayrıntılarını ele aldıklarından problemlerini çözüme kavuşturmaları güçtür.

Bağımlı olma, kişinin diğerlerinden özgür davranmaması ve kendisinden daha güçlü bir kişinin yaşamında olması gerektiğini düşünmesidir. Birey diğer insanlara karşı ne kadar itimat duyarsa o denli hayatındaki amaç ve isteklerden vazgeçmeye gereksinim duyar. Yardım ve yönlendirme için diğerlerine ne denli itimat duyarsa, kendisi o kadar az harekete geçer ve birey özgüvenini yitirir.
Onaylama ihtiyacı, bireyin yaşamında değer verdiği bütün kişiler tarafından kabul edilmeyi ve sevilmeyi çok güçlü bir şekilde istemesidir. Bu düşüncenin temeli kabul edilmenin ve sevginin arzu edilmekten ziyade ihtiyaç olarak belirmesidir. Herkes tarafından onaylama isteği ulaşılması imkânsız ve mükemmel bir amaçtır. Hatta birey yaşamındaki tüm bireyler tarafından kabul edilse de kabul edilme düzeyi ve sürekliliği ile ilgili kaygı duymaktadır.

Değişken tutum ise, Martin ve Anderson (1998)'e göre yaşamanın ne zaman ne getireceği belli değildir. Bundan dolayı bireylerin bilişsel esnekliğe ihtiyaçları vardır. Bireyin var olan değerlerinin, uyumsuzluk yaşandığında uyum gerçekleştirmeyi sağlayacak yapıda olması, kişinin farklı olaylara uyum sağlayabilme becerisi, esneklik durumundaki başarısı ve bireyin etkileşiminin farkında olmasıyla yakından ilgilidir. Başka bir ifadeyle anlatmak gerekirse, kişinin etkileşimde başvurduğu değişik metotları ne kadar farkında olarak kullandığı, farklı durumlar karşısında uyumu gerçekleştirebilme yeteneği ve esneklik gerektiren olaylarda yetkinlik beklentisinin veya tutumlarının var olmasıyla alakalıdır.

Yukarıda ifade edilen bilgiler göz önüne alındığında, bireyin var olan fonksiyonel olmayan tutumlarının hâlihazırdaki uyum düzeylerine etkisi olduğu söyleyebiliriz. Ancak alan yazın incelendiğinde uyumu fonksiyonel olmayan tutumlar açısından ele alan bir çalışmaya rastlanmamıştır. Özellikle insan yaşamında kritik bir öneme sahip olan üniversite yillarında ailelerinden uzakta eğitimlerine devam etmekte zorunda kalan çoğu genç, uyum düzeylerine olumsuz etki edebilecek çoğu durum ile tek başlarına mücadele etmek zorundadırlar. Dolayısıyla, üniversite öğrencilerinin deneyimledikleri yaşam olaylarının uyum düzeylerine olumsuz etki etmemesi açısından farklı değişkenlerin hâlihazırdaki uyum düzeylerine etkilerinin incelenmesi önemlidir. $\mathrm{Bu}$ sebeple bu araştırmada üniversite öğrencilerinin fonksiyonel olmayan tutumlarının genel, kişisel ve sosyal uyum düzeylerini yordama gücü belirlenmeye çalışılmıştır. Bu çalışmada elde edilen sonuçların ve sonuçlara dayalı olarak geliştirilen önerilerin uyum düzey ile ilgili çalışmalar yapan ruh sağlığı uzmanlarının çalışmalarına katkı sağlayacağı ve uyum kavramına farklı bir perspektiften yaklaşmalarını sağlayacağı düşünülmektedir.

Araştırmada aşağıda verilen sorulara yanıt aranmıştır:

(i) Üniversite öğrencilerinin fonksiyonel olmayan tutumlarının genel uyum düzeylerini yordama gücü nedir?

(ii) Üniversite öğrencilerinin fonksiyonel olmayan tutumlarının kişisel uyum düzeylerini yordama gücü nedir?

(iii) Üniversite öğrencilerinin fonksiyonel olmayan tutumlarının sosyal uyum düzeylerini yordama gücü nedir?

\section{Yöntem}

\subsection{Araştırma Modeli}

Bu çalışma ilişkisel modelde bir araştırmadır. Büyüköztürk, Kılıç-Çakmak, Akgün, Karadeniz ve Demirel (2016), göre başlıca örneklerini nedensel karşılaştırma ve korelasyonel 
yöntemlerin oluşturduğu ilişkisel araştırma genelde bağlantıları ve ilişkileri inceler.

\subsection{Evren ve Örneklem}

2017-2018 eğitim-öğretim y1lında Siirt Üniversitesinin eğitim süresi 4 yıl olan fakültelerinde eğitimlerine devam eden öğrenciler araştırmanın evrenini oluşturmaktadır. Araştırmanın örneklemi, 2017-2018 yılında Siirt Üniversitesinin farklı sınıf düzeylerinde eğitim almakta olan öğrencilerinden oluşmaktadır. Araştırmanın örneklemi hem fakültelerdeki öğrenci sayısının üniversitedeki öğrenci sayısını temsil etme oranı hem de sınıf düzeyinde öğrenci sayılarının fakültedeki öğrenci sayısını temsil etme oranı baz alınarak, oran tabakalı örnekleme yöntemiyle belirlenmiştir. Johnson ve Chrıstensen (2014)'de göre, oran tabakalı örnekleme yöntemi evrendeki özelliklerin temsil edilme düzeyleriyle, örneklemdeki temsil edilme düzeylerinin benzer olmasını gerektirir. Örneklemdeki kişi sayısının hesaplanmasında kabul edilebilir güven aralığı $\% 95$ olarak alınmış, 7000 kişilik bir evrende \%95'lik güven aralığı dikkate alındığında evreni temsil edecek tavsiye edilen örneklem büyüklüğü 364 kişidir (Krejecie,2004; Akt., Johnson ve Chrıstensen, 2014). Bu araştırmanın örneklemini oluşturan kişi sayısı aşağıdaki gibidir.

Tablo 1. Örneklemdeki Kişi Sayısı

\begin{tabular}{|c|c|c|c|c|c|c|c|c|c|}
\hline \multirow[t]{2}{*}{ Fakülteler } & \multicolumn{2}{|c|}{ 1. Sinıf } & \multicolumn{2}{|c|}{ 2.Sinıf } & \multicolumn{2}{|c|}{ 3. Sinıf } & \multicolumn{2}{|c|}{ 4. Sinıf } & \multirow[t]{2}{*}{ Toplam } \\
\hline & $\mathrm{K} 1 \mathrm{z}$ & Erkek & K1z & Erkek & $\mathrm{K} 1 \mathrm{z}$ & Erkek & $\mathrm{K} 1 \mathrm{z}$ & Erkek & \\
\hline İlahiyat Fakültesi & 15 & 14 & 13 & 14 & 16 & 13 & 14 & 11 & 110 \\
\hline Veteriner Fakültesi & 2 & 9 & 3 & 7 & 2 & 5 & 1 & 3 & 32 \\
\hline Ziraat Fakültesi & 6 & 8 & 1 & 4 & 2 & 4 & 1 & 2 & 28 \\
\hline Fen-Edeb. Fakültesi & 24 & 19 & 23 & 13 & 17 & 18 & 15 & 18 & 147 \\
\hline Eğitim Fakültesi & 30 & 22 & 37 & 25 & 37 & 29 & 42 & 45 & 267 \\
\hline $\begin{array}{l}\text { Mühendislik } \\
\text { Mimarlık Fakültesi }\end{array}$ & 5 & 14 & 3 & 10 & 4 & 14 & 8 & 20 & 78 \\
\hline $\begin{array}{lll}\text { İktisadi } & \text { ve } & \text { İdari } \\
\text { Bilim. } & & \\
\end{array}$ & 7 & 10 & 15 & 13 & 10 & 7 & 14 & 19 & 95 \\
\hline $\begin{array}{l}\text { YabanciDiller Yüksek } \\
\text { O. }\end{array}$ & 4 & 2 & 2 & 1 & - & - & - & - & 9 \\
\hline $\begin{array}{l}\text { Beden Eğitimi } \\
\text { ve Spor Yüksek O. }\end{array}$ & 10 & 21 & 10 & 20 & 7 & 16 & 3 & 6 & 93 \\
\hline $\begin{array}{l}\text { Sağlik } \\
\text { Yüksekokulu }\end{array}$ & 14 & 21 & 13 & 13 & 10 & 14 & 1 & 5 & 91 \\
\hline Toplam & 117 & 140 & 120 & 120 & 105 & 120 & 99 & 129 & 950 \\
\hline
\end{tabular}

Tablo 4 incelendiğinde, çalışmaya birinci sınıftan 257 (\%27), ikinci sınıftan 240 (\%25), üçüncü sinıftan 225 (\%24) ve dördüncü sinıftan 228 (\%24) öğrenci olmak üzere toplam 950 öğrenci katılmıştır. Bu öğrencilerin 441'i (\%46) k1z ve 509'u (\%54) erkek öğrenciden oluşmuştur.

\subsection{Veri Toplama Arac1}

\subsubsection{Kişisel Bilgi Formu}

Araştırmacının hazırladığı kişisel bilgi formu katılımcıların sınıf düzeyini, yaşını, cinsiyetini, ebeveynlerinin eğitim düzeyini, yaşamlarının büyük bir bölümünü geçirdikleri yeri, eğitim aldıkları fakülteyi, algıladıkları anne baba tutumunu ve sosyoekonomik düzeylerini belirleyen sorulardan oluşmuştur.

\subsubsection{Fonksiyonel Olmayan Tutumlar Ölçeği (FOTÖ)}

Ergen ve yetişkinlere uygulanabilen ölçek, bireylerin depresyonla alakalı olan işlevsel olmayan tutumlarının saptanması amaciyla Weissmen ve Beck tarafindan (1978) geliştirilmiştir. Şahin ve Şahin (1992) tarafından Türkçe’ye uyarlama çalışması yapılan ölçek 40 maddeden oluşmaktadır. Ölçek maddelere verilen cevaplara göre 1 ile 7 arasında değişen puanlar alan likert tipi bir ölçektir. Ölçekteki 10 madde, fonksiyonel olan tutum içeren maddeler olduğu için ters olarak puanlanması gerekir.
40 'tır. Ölçekten alınan puanlar yükselmesi, bireyin işlevsel olmayan tutumlarının sıklığını gösterir (Savaşır ve Şahin, 1997).Weissman ve Beck tarafindan öğrenci katılımcılarıyla yapılan çalışmalarda Cranbach alfa güvenirlik katsayılarının .87 ile .92 aralığında değerler aldığı bulunmuştur. Madde korelasyonlarının ise .20 ile .50 aralığında değerler aldığı bulunmuştur. Geçerlilik çalışmalarında ölçeğin Beck Depresyon Envanteriyle .30 ile .65 ve Otomatik Düşünceler Ölçeği ile .43 ile .64 arasında korelasyonu olduğu tespit edilmiştir. Test-tekrar test güvenirlik katsayıları .54 ile .84 arasında değişmektedir (Savaşır ve Şahin, 1997). Şahin ve Şahin tarafından yapılan Türkçeye uyarlama çalışmalarında Cranbach alfa güvenirlik katsayıs1 .75 ve madde toplam puan korelasyonlarının ortalaması .34 olarak bulunmuştur. Ölçekten elde edilen yarılama güvenirliği ise .72 olarak bulunmuştur. Ölçeğin Beck Depresyon Envanteri ile korelasyonu .19 ve Otomatik Düşünceler Ölçeği ile korelasyonu .29 olarak tespit edilmiştir. Yapılan faktör analizi sonucunda ölçeğin '’Mükemmelci tutum', “Onaylama ihtiyacı', "Bağımsız tutum" ve "Değişken tutum" olmak üzere 4 faktörden oluştuğu tespit edilmiştir (Savaşır ve Şahin, 1997).

\subsection{Verilerin Toplanmas1}

Araştırma verileri gerekli izinler alındıktan sonra, Siirt Üniversitesinin 4 yıllık fakültelerinde eğitimine devam 
eden örneklem grubundaki öğrencilerden, 2017-2018 eğitim-öğretim yılının güz döneminde toplanmıştır. Veri toplama araçları doldurulmadan önce, öğrencilere anketleri nasıl dolduracakları hakkında kısaca bilgi verilmiştir. Araştırmanın verilerinin toplanma süreci yaklaşık olarak 15-20 dakika arası sürdüğü için, öğrencilerin ölçekleri daha sağlıklı doldurmaları amacıyla isteyen öğrencilere ölçek sonuçlarını gerekli iletişim bilgilerini ölçeklere yazdıkları takdirde verileceği söylenmiştir. Verilerin toplanma aşamasında, merkez yerleşkede yer alan Sağlık ve Yabancı Diller Yüksekokulu ve Veterinerlik Fakültesi bir küme, Kezer yerleşkesindeki diğer fakülte ve yüksekokullar bir kümeye ayrılarak veriler toplanmıştır.

\subsection{Verilerin Analizi}

Üniversite öğrencilerinin uyum düzeylerini fonksiyonel olmayan tutumlarının anlamlı bir şekilde yordayıp yordamadığını belirlemek amacıyla çoklu regresyon analizi yapılmıştır. Bu çalışmada değişkenlerin tümü modele beraber dahil (standart yöntem) edilmiştir. Can (2016)'ya göre, bu yöntem bağımsız değişkenlerin, bağımlı değişken üzerindeki ortak etkisini görebilmek için yapılır. Bağımsız değişkenlerin modele hangi şekilde dahil edileceği sonuçları etkilemektedir. Ayrıca çoklu regresyon yapılmadan önce bağımsız değişkenlerin arasındaki ilişkinin 0.80'nin üstünde olmaması gerekir (Büyüköztürk, 2018). Ayrıca regresyon analizinde bazı uç değerler sonuçların sağlıklı olmasını engellemektedir. Çalışmacı isterse bu uç değerleri devre dışı bırakabilir. Bunun için Mahalanobis uzaklıkları hesaplanıp belirli bir sınırı aşan değerler regresyon modelinden çıkarılabilir (Can, 2016). Bunun için Kay-Kare dağılım tablosu kullanılabilir. Yordayıcı değişken sayısının 4 olduğu çalışmacının tutucu davrandığ 0.01 anlamlılık düzeyinde Mahalanobis değeri 13.277 ve üstü değerler çalışmadan çıkarılabilir (Büyüköztürk, 2018). Bu çalışmada yapılan regresyon analizinde yordayıcı değişken sayısı 4'tür ve 0.01 anlamlılık düzeyi seçilmiştir.

\section{Bulgular}

Araştırmanın bu bölümü veri toplama araçları ile toplanan verilere ait bulgulardan oluşmaktadır. Üniversite öğrencilerinin fonksiyonel olmayan tutumlarına ait betimsel istatistikler, genel, kişisel ve sosyal uyum düzeyinin fonksiyonel olmayan tutumlarla arasındaki ilişkiler ve çoklu regresyon sonuçları aşağıda tablolar halinde sunulmuştur.

3.1 Üniversite öğrencilerinin fonksiyonel olmayan tutumlarına ilişkin betimsel istatistiki bulgular

Tablo 2. Üniversite Öğrencilerinin Fonksiyonel Olmayan Tutumlar ve Alt Boyutlarına İlişkin Betimsel İstatistikler

\begin{tabular}{lccc}
\hline Boyut & $\mathrm{N}$ & $X$ & $\mathrm{Ss}$ \\
\hline Fonksiyonel $\quad$ Olmayan & & 121.4521 & 26.01965 \\
Tutum & 950 & & \\
Değişken Tutum & 950 & 18.9221 & 4.67739 \\
Bağımsız Tutum & 950 & 17.9189 & 6.5080 \\
Mükemmeliyetçilik & 950 & 45.8326 & 14.91904 \\
Onaylama & 950 & 38.7442 & 10.68718 \\
\hline
\end{tabular}

Tablo 2'ye göre, üniversite öğrencilerinin fonksiyonel olmayan tutumlar ortalaması $\quad(\bar{X}=121.4521)$ bulunmuştur. Ayrıca, değişken tutum ortalaması $(\bar{X}=18.9221)$, bağımsız tutum ortalaması $(\bar{X}=17.9189), \quad$ mükemmeliyetçilik ortalamas1 $(\bar{X}=45.8326) \quad$ ve onaylama ortalamas1 $(\bar{X}=38.7442)^{\prime}$ dir.

3.2. Üniversite öğrencilerinin fonksiyonel olmayan tutumları ile uyum düzeyleri arasındaki ilişkiye ait bulgular

Tablo 3. Üniversite Öğrencilerinin Genel Uyum Düzeyleri ve Alt ölçekleri ile Fonksiyonel Olmayan Tutumlar ve Alt Ölçekleri Arasındaki Pearson Korelasyon Katsayısı Değerleri

\begin{tabular}{|c|c|c|c|c|c|c|c|c|}
\hline & 1 & 2 & 3 & 4 & 5 & 6 & 7 & 8 \\
\hline 1.Genel Uyum & -- & $.915 * *$ & $.903 * *$ & $-.290 * *$ & $-.110 * *$ & $-.197 * *$ & $-.233 * *$ & $-.209 * *$ \\
\hline 2.Kişisel Uyum & $.915 * *$ & -- & $.682 * *$ & $-.247 * *$ & $-.084 * *$ & $-.147 * *$ & $-.186 * *$ & $-.213 * *$ \\
\hline 3.Sosyal Uyum & $.903 * *$ & $.682 * *$ & -- & $-.281 * *$ & $-.109 * *$ & $-.217 * *$ & $-.249 * *$ & $-.153 * *$ \\
\hline 4.FOTÖ & $-.290 * *$ & $-.247 * *$ & $-.281 * *$ & --- & $.344 * *$ & $.518 * *$ & $.868 * *$ & $.769 * *$ \\
\hline 5.Değişken $T$. & $-.110 * *$ & $-.084 * *$ & $-.109 * *$ & $.344 * *$ & --- & $.304 * *$ & $.107 * *$ & $074 *$ \\
\hline 6.Bağımsız T. & $-.197 * *$ & $-.147 * *$ & $-.217 * *$ & $.518 * *$ & .304 & --- & $.253 * *$ & $.190 * *$ \\
\hline 7.Mükemmelliyetçilik & $-.233 * *$ & $-.186 * *$ & $-.249 * *$ & $.868 * *$ & $.107 * *$ & $.253 * *$ & --- & $.524 * *$ \\
\hline
\end{tabular}

$(*)=\mathbf{p}<0.5 ;(* *)=\mathbf{p}<0.1$

Tablo 3'e göre genel, kişisel ve sosyal uyum düzeylerini yordadığı düşünülen fonksiyonel olmayan tutumlar alt ölçeklerinin kendi arasındaki ikili korelasyon katsayıları çoklu bağlantı sorunu oluşturabilecek değer olan .8 altındadır. Bu değerler .074 ve .524 arasında değişmektedir. Genel uyum düzeyi ile fonksiyonel olmayan tutumlar arasında $(\mathrm{r}=-.290, \mathrm{p}=<.01)$, kişisel uyum düzeyi ile fonksiyonel olmayan tutumlar arasinda $(\mathrm{r}=-.247, \mathrm{p}<.01)$, sosyal uyum düzeyi ile fonksiyonel olmayan tutumlar arasında $(\mathrm{r}=-.281, \mathrm{p}<.01)$, genel uyum düzeyi ile değişken tutum arasında $\quad(\mathrm{r}=-.110, \mathrm{p}<.01)$, genel uyum düzeyi ile bağımsız tutum arasında $(\mathrm{r}=-.197, \mathrm{p}<.01)$, genel uyum düzeyi ile mükemmeliyetçilik arasında $(\mathrm{r}=-.233)$ ve genel uyum düzey ile onaylama ihtiyacı arasında $(r=-.209, \mathrm{p}<.01)$ negatif yönlü anlamlı ilişki bulunmuştur. Ayrıca uyum düzeyleriyle fonksiyonel olmayan tutumlar arasındaki ilişkiler beklenildiği gibi negatif yönde çıkmıştır. 
3.3. Üniversite öğrencilerinin fonksiyonel olmayan bulgular tutumlarının uyum düzeylerini yordama gücüne ait

Tablo 4. Öğrencilerin Fonksiyonel Olmayan Tutumlar Alt Ölçeklerinin Genel Uyum Düzeyini Yordamasına İlişkin Çoklu Regresyon Analiz Sonucu

\begin{tabular}{|c|c|c|c|c|c|c|c|}
\hline Değişkenler & B & $\begin{array}{c}\text { Standart } \\
\text { Hata }\end{array}$ & $\beta$ & $\mathrm{t}$ & $\mathrm{p}$ & İkili r & Kismi r \\
\hline Sabit & 112.925 & 3.483 & - & 32.424 & 0.00 & - & - \\
\hline MükemmeliyetçiT & -0.187 & 0.050 & $\begin{array}{c}- \\
0.138\end{array}$ & -3.713 & 0.00 & -0.233 & -0.120 \\
\hline Onaylama İh & -0.205 & 0.069 & $\begin{array}{c}- \\
0.108\end{array}$ & -2.961 & 0.003 & -0.209 & -0.096 \\
\hline Bağımsız T. & -0.433 & 0.108 & $\begin{array}{c}- \\
0.134\end{array}$ & -4.013 & 0.00 & -0.202 & -0.129 \\
\hline Değişken $T$. & -0.202 & 0.141 & $\begin{array}{c}- \\
0.047\end{array}$ & $-1,433$ & 0.152 & -0.110 & -0.047 \\
\hline $\begin{array}{l}\mathrm{R}=0.295 \\
\mathrm{~F}_{(4-946)=22.524}\end{array}$ & $\begin{array}{l}\mathrm{R}^{2}=0.087 \\
\mathrm{p}=0.000\end{array}$ & & & & & & \\
\hline
\end{tabular}

Tablo 4 incelendiğinde, öğrencilerin genel uyum düzeyine etkisi olduğu düşünülen mükemmeliyetçi tutum, onaylanma ihtiyacı, bağımsız tutum ve değişken tutum değişkenlerinin, öğrencilerin uyum düzeyini ne şekilde yordadığını belirlemeye yönelik olarak gerçekleştirilen çoklu doğrusal regresyon analizi neticesinde, mükemmeliyetçi tutum, onaylanma ihtiyacı, bağımsız tutum ve değişken tutum değişkenleri beraber genel uyum düzeyi ile anlamlı düzeyde bir ilişki $\left(\mathrm{R}=0.295, \mathrm{R}^{2}=0.087\right)$ göstermişlerdir $\quad\left(\mathrm{F}_{(4-}\right.$ $\left.{ }_{946)}=22.254, \mathrm{p}<0.01\right)$. Ele alınan dört yordayıcı değişken, beraber, genel uyum düzeyindeki değişimin \%8.7'sini açıklamaktadır. Standartlaştırılmış regresyon katsayıları açısından, genel uyum düzeyi üzerindeki göreli önem sırası,

Tablo 5. Öğrencilerin Fonksiyonel Olmayan Tutumlar Alt Ölçeklerinin Kişisel Uyum Düzeyini Yordamasına İlişkin Çoklu Regresyon Analiz Sonucu

\begin{tabular}{lccccccc}
\hline Değişkenler & $\mathrm{B}$ & $\begin{array}{c}\text { Standart } \\
\text { Hata }\end{array}$ & $\beta$ & $\mathrm{t}$ & $\mathrm{p}$ & İkili r & K1smi r \\
\hline Sabit & 51.627 & 2.064 & - & 25.009 & 0.00 & - & - \\
MükemmeliyetçiT & -0.064 & 0.030 & -0.081 & -2.160 & 0.031 & -0.187 & -0.070 \\
Onaylama İh & -0.171 & 0.041 & -0.154 & -4.154 & 0.000 & -0.215 & -0.134 \\
Bağımsız T. & -0.161 & 0.065 & -0.085 & -2.487 & 0.013 & -0.147 & -0.081 \\
Değişken T. & -0.103 & 0.084 & -0.041 & -1.233 & 0.218 & -0.086 & -0.040 \\
\hline $\mathrm{R}=0.254$ & $\mathrm{R}^{2}=0.064$ & & & & & &
\end{tabular}

Tablo 5 incelendiğinde, öğrencilerin kişisel uyum düzeyine etkisi olduğu düşünülen, mükemmeliyetçi tutum, onaylanma ihtiyacı, bağımsız tutum ve değişken tutum değişkenlerinin, öğrencilerin kişisel uyum düzeyini ne şekilde yordadığını belirlemeye yönelik olarak gerçekleştirilen çoklu doğrusal regresyon analizi neticesinde, mükemmeliyetçi tutum, onaylanma ihtiyacı, bağımsız tutum ve değişken tutum değişkenleri birlikte genel uyum düzeyi ile anlamlı düzeyde bir ilişki $(\mathrm{R}=0.254$, $\left.\mathrm{R}^{2}=0.087\right)$ göstermişlerdir $\left(\mathrm{F}_{(4-946)}=22.254\right.$, $\left.\mathrm{p}<0.01\right)$. Ele alınan dört yordayıcı değişken, beraber, kişisel uyum düzeyindeki değişimin \%6,4'ni açıklamaktadır. Standartlaştırılmış regresyon katsayıları açısından, yordayıcı değişkenlerin, kişisel uyum düzeyi üzerindeki göreli önem sırası, onaylanma ihtiyacı ( $\beta=-0.154)$, bağımsız mükemmeliyetçi tutum $(\beta=-0.138)$, bağımsız tutum $(\beta=-$ $0.134)$, onaylanma ihtiyacı $(\beta=-0.108)$ ve değişken tutum $(\beta=-0.047)$ 'dır. Regresyon katsayılarının anlamlılık testlerine göre, onaylama ihtiyac1 $(\mathrm{p}<0.01)$, mükemmeliyetçi tutum $(\mathrm{p}<0.01)$ ve bağımsı tutum $(p<0.01)$ genel uyum düzeyini anlamlı olarak yordamaktadir. Regresyon analizinden elde edilen sonuçlarına göre, sosyal uyum düzeyini yordayan regresyon formülü aşağıda verilmiştir:

Genel Uyum Düzeyi $=(-0.202 \times$ Değişken Tutum Ölçek Puanı) $+(-0.205 \times$ Onaylanma İhtiyacı Ölçek Puanı)+ (-0.187× Mükemmeliyetçi Tutum Ölçek Puanı) $+(-0.433 \times$ Bağımsız Tutum Ölçek Puanı) + (112.925). 
Tablo 6. Öğrencilerin Fonksiyonel Olmayan Tutumlar Alt Ölçeklerinin Sosyal Uyum Düzeyini Yordamasına İlişkin Çoklu Regresyon Analiz Sonucu

\begin{tabular}{lllccccc}
\hline Değişkenler & \multicolumn{1}{c}{$\mathrm{B}$} & $\begin{array}{c}\text { Standart } \\
\text { Hata }\end{array}$ & $\beta$ & $\mathrm{t}$ & $\mathrm{p}$ & İkili r & K1smi r \\
\hline Sabit & 60.790 & 1.769 & - & 34.369 & 0.000 & - & - \\
MükemmelciT & -0.137 & 0.026 & -0.199 & -5.357 & 0.000 & -0.252 & -0.172 \\
Onaylama İh & -0.021 & 0.035 & -0.021 & -0.586 & 0.558 & -0.157 & -0.019 \\
Bağımsız T. & -0.246 & 0.055 & -0.149 & -4.445 & 0.000 & -0.217 & -0.143 \\
Değişken T. & -0.096 & 0.072 & -0.044 & -1.345 & 0.179 & -0.112 & -0.044 \\
\hline $\mathrm{R}=0.301$ & $\mathrm{R}=0.091$ & & & & & \\
$\mathrm{~F}(4-946)=23.540$ & $\mathrm{p}=0.000$ & & & & & &
\end{tabular}

Tablo 6 incelendiğinde, öğrencilerin sosyal uyum düzeyi üzerinde etkisi olduğu düşünülen, mükemmelci tutum, onaylanma ihtiyacı, bağımsız tutum ve değişken tutum değişkenlerinin, öğrencilerin sosyal uyum düzeyini ne şekilde yordadığını belirlemeye yönelik olarak gerçekleştirilen çoklu doğrusal regresyon analizi neticesinde, mükemmeliyetçi tutum, onaylanma ihtiyacı, bağımsız tutum ve değişken tutum değişkenleri beraber sosyal uyum düzeyi ile anlamlı bir ilişki $(\mathrm{R}=0.301$, $\mathrm{R} 2=0.091)$ göstermişlerdir $\left(\mathrm{F}_{(4-946)}=23.540, \mathrm{p}<0.01\right)$. Ele alınan dört yordayıcı değişken, beraber, sosyal uyum düzeyindeki değişimin \%9,1'ni açılamaktadır. Standartlaştırılmış regresyon katsayıları açısından, yordayıcı değişkenlerin, sosyal uyum düzeyi üzerindeki göreli önem sıras1, mükemmeliyetçi tutum $(\beta=-0.199)$, bağımsız tutum $(\beta=-0.149)$, değişken tutum $(\beta=-0.044)$ ve onaylanma ihtiyac1 $(\beta=-0.021)$ 'dir. Regresyon katsayılarının anlamlılık testlerine göre, mükemmeliyetçi tutum $(\mathrm{p}<0.01)$ ve bağımsız tutum $(\mathrm{p}<0.01)$ sosyal uyum düzeyini anlamlı olarak yordamaktadır. Regresyon analizinden elde edilen sonuçlarına göre, sosyal uyum düzeyini yordayan regresyon formülü aşağıda verilmiştir:

Sosyal Uyum Düzeyi= $(-0.0096 \times$ Değişken Tutum Ölçek Puanı) $+(-0.021 \times$ Onaylanma İhtiyacı Ölçek Puanı) $+(-0.137 \times$ Mükemmelci Tutum Ölçek Puanı) $+(-0.246 \times$ Bağımsız Tutum Ölçek Puanı) + (60.790).

\section{Tartışma ve Sonuç}

Fonksiyonel olmayan tutumlar genel uyum düzeyine ilişkin toplam varyansın $\% 8.7$ 'sini, kişisel uyum düzeyine ilişkin toplam varyansin \% 6.4'nü ve sosyal uyum düzeyine ilişkin toplam varyansın \%9.1'ni açıklamaktadır. Ayrıca hem genel hem kişisel hem de sosyal uyum düzeyleri ile fonksiyonel olmayan tutumlar ölçeği ve alt ölçeklerinden alınan puanlar arasında beklenildiği gibi negatif anlamlı bir ilişki bulunmuştur. Araştırmada üniversite öğrencilerinin fonksiyonel olmayan tutumlar alt ölçeklerden genel ve kişisel uyumu anlamlı olarak yordayan değişkenler mükemmeliyetçi tutum, bağımsız tutum ve onaylama ihtiyacıdır. Sosyal uyum düzeyini ise anlamlı olarak yordayan değişkenler mükemmeliyetçi tutum ve bağımsız tutumdur. Literatür tarandığında benzer çalışmalar olmadığından araştırma sonuçlarının diğer çalışmalarla karşılaştırma imkânı olmamıştır.

Mükemmeliyetçilik, bireyin sorunlarının kusursuz bir çözümü olduğu ve tek bir doğru olduğu fikrine sahip olmasıdır. Bireyin karşılaştığı sorunları çözme adına olası ve pratik olanı istemesi mantıklıdır. Fakat sürekli olarak kusursuz çözüm yöntemlerini araması fonksiyonel olmayan bir tutumdur. Mükemmeliyetçi bireyler problemlerini çözüme kavuşturacak yolların bütün ayrıntılarını ele aldıklarından problemlerini çözüme kavuşturmaları güçtür (Akt.,Yurtal-Dinç,1999). Çünkü birey karşılaştığı her türlü sorunu çözüme kavuşturup uyuma geçebilme sürecinde tek doğru bir çözüm yolu olduğunu düşünürse ve kusursuz olan yönteme ulaşmaya çalışırsa sorunları çözüme kavuşturması ve harekete geçmesi güçleşecek bu durumun neticesindede uyuma geçebilmesi zorlaşacaktır. Dolayısıyla araştırmada genel, sosyal ve kişisel uyum düzeyi ile mükemmeliyetçilik puanları arasında negatif anlamlı bir ilişki çıkması ve mükemmeliyetçilik tutumunun genel, sosyal ve kişisel uyumu anlamlı olarak yordamasının anlamlı olduğu düşünülmektedir.

Bağımlı olma, kişinin diğerlerinden özgür davranmaması ve kendisinden daha güçlü bir kişinin yaşamında olması gerektiğini düşünmesidir. Birey diğer insanlara karşı ne kadar itimat duyarsa o ölçüde hayatındaki amaç ve istekleri bırakmaya gereksinim duymaktadır. Yardım ve yönlendirme için diğerlerine ne denli itimat duyarsa, kendisi o kadar az harekete geçer ve birey özgüvenini yitirir. Böylece öz kontrolünü gerçekleştiremez ve diğer insanlara bağımlı olur (Akt.,Yurtal-Dinç,1999). Bağımsız davranamayan bireyler, kendilerine olan güvenleri düşük olduğundan dolayı problemlerini çözüme kavuşturmada tek başına harekete geçemeyecekleridir. Bağımlı olduğu kişiler yaşamlarında olmadıklarında günlük yaşamlarına devam etmekte zorluk yaşamaktadırlar. Bunun neticesinde de uyum düzeyleri düşebilmektedir. Dolayısıyla araştırmada genel, sosyal ve kişisel uyum düzeyi ile bağımlı olma puanları arasında negatif anlamlı bir ilişki çıkması ve bağımlı tutumunun genel, sosyal ve kişisel uyumu anlamlı olarak yordamasının anlamlı olduğu düşünülmektedir. Nitekim Akıncı (2007) göre, bireyin sağlıklı uyuma geçebilmesi için, problemleri karşısında ve yaşamında pasif bir rol almaması gerekmektedir.

Onaylama ihtiyacı, bireyin yaşamında değer verdiği bütün kişiler tarafindan kabul edilmeyi ve sevilmeyi çok güçlü bir şekilde istemesidir. Bu düşüncenin temeli kabul edilmenin ve sevginin arzu edilmekten ziyade ihtiyaç olarak belirmesidir. Herkes tarafından onaylama isteği ulaşılması imkânsız ve mükemmel bir amaçtır. Hatta birey yaşamındaki tüm bireyler tarafından kabul edilse de kabul edilme düzeyi ve sürekliliği ile ilgili kaygı duymaktadır (Akt.,Yurtal-Dinç,1999). Çevresindeki diğer kişiler tarafindan sürekli sevilme ve takdir görme ihtiyacı içinde olan bireyin yaşamından doyum alması ve yaşamını ruhsal açıdan sağlıklı bir şekilde sürdürebilmesi zorlaşacaktır. $\mathrm{Bu}$ durumununda bireyin uyum düzeyini düşürebilecektir. Dolayısıyla araştırmada genel ve kişisel uyum düzeyi ile 
onaylama ihtiyacı puanları arasında negatif anlamlı bir ilişki çıkması ve onaylama ihtiyacının genel ve kişisel uyumu anlamlı olarak yordamasının anlamlı olduğu düşünülmektedir.

\section{5. Öneriler}

Araştırmanın amaçları doğrultusunda öğrencilere uygulanan ölçekten elde edilen bulguların analiz edilmesinin ardından şu önerilerde bulunulabilir:

(i) PDR birimleri veya alan uzmanlarınca üniversite öğrencilerinin uyum düzeylerini yükseltmek amacıyla, fonksiyonel olmayan tutumlar ve etkileri konularında farkındalık düzeylerini artıcı çalışmalar yapılabilir.

(ii) Fonksiyonel olmayan tutumların 4 alt boyutunun, genel uyum düzeyindeki değişimin \%8,7'sini, kişisel uyum düzeyindeki değişimin \%6,4'ni ve sosyal uyum düzeyindeki değişimin \%9,1'ni açıkladığı bulunmuştur. Dolayısıyla uyum kavramının daha net bir şekilde açıklanabilmesi için uyum düzeyine etkisi olabilecek farklı değişkenler araştırmacılar tarafından incelenebilir.

(iii) Farklı kültürdeki, farklı örneklem gruplarıyla fonksiyonel olmayan tutumların uyum düzeyine etkisi açısından yapılan çalışmalarda farklı sonuçlar elde edilebileceği araştırmacılar tarafından göz ardı edilmemelidir.

(iv) $\mathrm{Bu}$ çalışma Siirt Üniversitesinde öğrenimlerine devam eden öğrencilerin ölçeklere verdikleri cevaplarla sınırlıdır. $\mathrm{Bu}$ sebeple araştırma sonuçlarının genellenebilirliği açısından farklı üniversitede öğrenimlerine devam eden öğrenciler üzerinde araştırmacılar tarafından benzer çalışmalar yapılabilir.

\section{Kaynakça}

Akıncı, G., (2007), Engelli Çocuğa Sahip Olan ve Olmayan Babaların Aile İşlevlerini Algllamaları İle Sosyal Uyum Düzeylerinin Incelenmesi. (Yayımlanmamış Yüksek Lisans Tezi). Ankara Üniversitesi/ Fen Bilimleri Enstitüsü, Ankara.
Benight, C. C. ve Bandura, A. (2004). Social cognitive theory of posttraumatic recovery: The role of perceived selfefficacy. Behavior Research and Therapy, 42, 11291148.

Büyüköztürk, Ş. (2018). Sosyal bilimler için veri analizi el kitabı istatistik, araştırma deseni spss uygulamaları ve yorum. Ankara: Pegem.

Büyüköztürk, Ş., Çakmak, E.K., Akgün, Ö.E., Karadeniz, Ş. Ve Demirel, F. (2016). Bilimsel Araştırma yöntemleri. Ankara: Pegem.

Can, A. (2016). Spss ile bilimsel araştırma sürecinde nicel veri analizi. Ankara: Pegem.

Cüceloğlu, D. (2015). Insan ve davranışı. İstanbul: Remzi.

Gençöz, F. (1998). Uyum Psikolojisi. Kriz Dergisi. 6(2), 17.

Johnson, B. ve Chrıstensen, L. (2014). Eğitim araştırmaları nicel, nitel ve karma yaklaşımlar. (Çev. Ed. Ş.B. Demir). Ankara: Eğiten Kitap.

Kramer, G.P, Berntein, D.A. ve Phares, V. (2014). Klinik psikolojiye giriş. (Çev. Ed. İ. Dağ). Ankara: Mentis Yayıncilik.

Martin, M.M. and Anderson , C. M. ( 1998 ). The cognitive flexibility scale three validity studies . Communication Reports , 11, $1-9$.

Murdock, N.L. (2016). Psikolojik danışma ve psikoterapi kuramlar. (Çev. Edt. F.Akkoyun ). Ankara: Nobel.

Özgüven, İ.E. (1992). Hacettepe kişilik envanteri el kitabl. Ankara: Odak Ofset Matbaacilık.

Savaşır, I. ve Şahin, N.H. (1997). BiIişsel davranıșçı terapilerde değerlendirme: Sık kullanılan ölçekler. Ankara: Türk Psikologlar Derneği Yayınları.

Yavuzer, H. (2003). Çocuk psikolojisi. İstanbul: Remzi Yayıncılık.

Yurtal-Dinç, F. (1999). Üniversite ögrrencilerinin akılcı olmayan inançlarının bazı değişkenlere göre incelenmesi. (Yayınlanmamış Doktora Tezi). Gazi Üniversitesi/Eğitim Bilimleri Enstitüsü, Ankara.

Yurtal-Dinç, F. (2001). Akılcı Olmayan inançların bazı değişkenlere göre incelenmesi. Türk Psikolojik Danışma ve Rehberlik Dergisi, 2, 41-48. 